\title{
CREDIT MANAGEMENT STRATEGIES AND FINANCIAL PERFORMANCE OF INDUSTRIAL GOODS SECTOR IN NIGERIA
}

\author{
Ismail Alhassan \\ Department of Accounting \\ School of Business Education, Federal College of Education \\ (Technical), Gombe, Gombe State, Nigeria \\ E-mail: alhassan1412@gmail.com \\ K. M. Anwarul Islam \\ Associate Professor \\ Department of Business Administration \\ The Millennium University, Dhaka, Bangladesh \\ E-mail:anwarul@themillenniumuniversity.edu.bd
}

Received: August 30, $2021 \quad$ Accepted: November 15, $2021 \quad$ Online Published: December 14, 2021

DOI: $10.46281 / \mathrm{ijfb} . v 8 \mathrm{i} 1.1495$

URL: https://doi.org/10.46281/ijfb.v8i1.1495

\begin{abstract}
The influence of credit management methods on the liquidity and profitability of listed industrial goods firms in Nigeria was investigated in this study. It was decided to use a descriptive survey study design. The sample population for which copies of the questionnaire were distributed was 400 respondents, representing $65 \%$ of the population. The participants provided 355 valid responses, which were examined. For descriptive statistics, one-way ANOVA was utilized, and to test the hypotheses, a basic regression analysis method was applied. The results showed that the credit risk assessment, debt recovery strategy, and receivable collection policy sub-variables have a positive and statistically significant impact on the liquidity sub-variables - ability to pay, level of bad debt, and cash inflow. Liquidity had a positive and statistically significant effect on profitability. The study thus, suggest that companies in the industry should enhance their liquidity in order to achieve the targeted profit level by having effective credit terms and proper risk assessment strategy, designing and implementing debt recovery plans to aid collection of the overdue debt, adopting a stringent credit collection method, and employing and retained qualified accountants and credit administrators with excellent knowledge of credit control techniques.
\end{abstract}

Keywords: Credit Management Strategies, Credit Sales, Industrial Goods, Liquidity.

JEL Classification Codes: F65.

\section{INTRODUCTION}

For quite a long time marketing professionals have recognized that giving credit is one of the tactics used by businesses to increase sales volume. It serves as a critical marketing link for the transportation of goods from manufacturing to distribution to a large number of customers who cannot pay right away. In the firm's statement of financial position, trade credit establishes an account receivable, which the firm records under current assets and anticipates to receive in the future. Apart from increased sales 
volume, companies give credit to consumers for a variety of reasons, including gaining a large percentage of the industry market, achieving a certain level of profit, commanding client loyalty, and retaining customers in the company (Wireko \& Forson, 2017). In credit transactions, the economic worth of the items flows to the buyer at the time of purchase, but the seller anticipates receiving an equivalent amount at a later period. The seller may face some liquidity risk as a result of a partial or complete payment delay at the moment of sale (Kaitibi1, Ganawah, Yokie, Jalloh, \& Koroma, 2018). As a result, credit sales imply both current and future transactions, posing a receivable risk that must be carefully assessed and handled. Credit is unavoidable in any business circle, yet it remains a threat to any company's financial health and performance (Agu \& Basil, 2013; Nwanna \& Oguezue, 2017).

Many quoted industrial businesses in Nigeria have failed because to a lack of liquidity to launch sustainable investments, resulting in lower profitability levels to continue operations, according to previous studies (Owolabi \& Obida, 2012; Ifurueze, 2013). Bad debts from consumers who were unable to pay for products offered to them on credit when they were due accounted for a large portion of the liquidity problem. To increase sales, several manufacturing corporations give customers a lot of credit at the expense of liquidity, volume and control of a fair part of the industry market are prioritized. A corporation with sufficient liquidity can satisfy its short-term operating obligations to creditors and invest in promising ventures. Profitability would be boosted by proper investments, such as in projects with a positive net present value, as well as quick creditor payment and a cash discount advantage (Banu, Sayaduzzaman, \& Sil 2021). Long-term credit without a credit policy to control debts will have a detrimental impact on liquidity and profitability (Raymond \& Adigwe, 2015). To assess, manage, and avoid bad debts, a firm should use credit analytical tools and tactics created by credit professionals. Management uses sound credit sales to maximize debt collection, reduce credit expenses, and provide credit solely to creditworthy consumers in order to eliminate the problem of bad debts and improve cash flow. To stay ahead of the competition, businesses should develop competitive financing conditions (Ofoegbu, Duru, \& Onodugo, 2016).

Management should control credit to guarantee adequate liquidity, according to Owolabi and Obida (2012), by designing an acceptable credit model that would offer a collection of receivables at appropriate time. Credit terms and client risk assessment, credit collection, and better debt recovery at low cost are all part of the plan. According to Ifurueze (2013), proper liquidity has a considerable moderating effect on an organization's profitability. This assumption has prompted the question of how credit management practices affect liquidity and, as a result, profit. In Nigeria's chemical and paint manufacturing subsector, the answer to this study question was omitted. As a result, further research is needed to determine the influence of credit management practices on the liquidity and profitability of businesses.

The overall goal of this study is to look into the impact of credit management practices on the liquidity and profitability of Nigerian industrial goods sector. The subsidiary objectives to achieve the main goal are: to examine the impact of credit conditions and risk assessment on the customer's ability to pay; to examine the impact of debt collection method on the customer's ability to pay, to assess the impact of credit collection policy on the company's cash flow and to assess the extent of bad debt. Credit management procedures in industrial goods sector whose instruments are not traded on the Nigeria stock market floor, as well as companies in other sub-sectors, were excluded from this study. The study's justification is to contribute to the literature by providing analytical evidence on the link between the variables. Managers in the manufacturing industry, researchers pursuing more research in this area, bankers, and analysts would all benefit from the findings. The research could potentially be used as a reference material for credit management applications.

\section{The Concept of Credit Management Strategies}

\section{LITERATURE REVIEW}

One of the most essential decisions sellers must make is whether or not to issue credit, and if so, how the credit will be managed. Credit control decisions differ from one business to the next, yet certain firms' decision templates may be similar, especially within the same industry (Okpala, Osanebi, \& 
Irinyemi 2019). Though credit sales transactions create trade debts in a business, they can also result in questionable and bad debts in some situations. Where existence is dependent on the volume of turnover, credit sales, regardless of the risk, is critical (Khan, Tragar, \& Bhutto, 2012). According to the debtors' payment strength, debt can be classed as excellent, dubious, or terrible. The quality of accounts accepted by the firm, the state of the purchasers' country, and credit management practices are all factors that influence the extent of dubious or bad debt losses (Kamal 2021). The danger of questionable and bad debts can be reduced when debtors are properly managed. While improper trade debt management can result in a high sum of money being set aside for dubious and debt debts, bad debt losses occur when a company is unable to collect its receivables (Adegboye, 2021; Agu \& Basil, 2013).

Regardless of the virtues of credit sale in accomplishing firms' objectives, according to Uzoh (2012), it was proven to be accountable for financial failure in some manufacturing organizations, particularly when trade credits were not adequately managed. Most companies overlook the risk connected with sale credits and utilize it as a marketing technique in order to increase sales to beat the competition, increase customer loyalty, encourage additional cash flow, and aid in negotiating leverage. When the degree of competition in the industry is high, a firm will provide more credit and will have strong bargaining power if it has a strong product, monopoly power, brand name, huge size, and strong financial position. Credit sales are also used as a marketing tactic when a new product is brought to the market or when a corporation wants to push a product that isn't performing well (Ehiedu, 2014).

\section{Credit Management Strategies}

The terms policy and strategy have been used interchangeably in the past. A strategy is a special plan created to gain a market position and meet the company's objectives, whereas a policy is a set of guidelines created by the organization for rational decision making. As a result, policies take second place to strategy. Credit management policy is an operational document that lays out several operating rules for the credit sales process that the entire organization must follow when granting credit to customers (Taiwo \& Abayomi, 2013). This research focused on credit management strategy, which is defined as a design that assists a firm in achieving organizational credit objectives, gaining customer trust, gaining a competitive edge through sales volume, and gaining a solid market position. A firm's intended position is achieved by a combination of well-thought-out intent and actions. This organizational approach aims to be effective (raise sales), manage events and problems (financial risk), capitalize on opportunities (increase cash inflow), fully utilize resources (make suitable expenditures), and deal with threats (reducing bad debt losses). Credit sales are managed, and bad debt losses are reduced using the credit management technique. Establishing credit conditions, credit information analysis and scoring to determine credit worthiness of organizations and individuals, and developing credit plans to aid receivable collections when due are all routine practices of credit management (Ifurueze, 2013).

\section{Establishment of Terms of Credit}

The terms of credit refer a combination of three factors: the period of credit, cash discount, and the type of credit instrument employed. Credit periods refer to the time between sales and payment, which varies depending on the industry and the type of items supplied. When determining a credit period, a corporation must assess the likelihood that the client would not pay on the due date, the size of the account to allow for a shorter credit period for smaller accounts and vice versa (Akinleye, \& Olarewaju 2019). The degree of durability of the collateral used as security is also important. Secondly, a monetary discount is frequently permitted as part of the loan terms, and the purpose of the rebate is to expedite the collection of receivables. Finally, the invoice is commonly used as a credit sales tool. A seller sends a customer an invoice to sign as proof of receipt of goods, which also serves as a source document for the receivable accounting record (Akinsulire, 2017). 


\section{Analysis and Scoring of Credit Information}

Credit information analysis and scoring are two methods for determining a prospective customer's creditworthiness (firm or individual) and influencing the quality of the firm's customers who are provided credit (Ifurueze, 2013). Financial statements of the prospective credit customer are a common source of information used to assess a customer's creditworthiness. The seller would then be able to perform a ratio analysis. The customer's payment history, the quantity of the customer's important assets, at least three trade credit references, and full details of all directors, partners, or owners are also necessary for credit reports. Customers who are financially vulnerable should be required to submit a "credit bond" from a reputable financial institution (Akinsulire, 2017). It is based on these factors that the decision to award or deny credit is made. The defined criteria for evaluating credit risk, according to Ifurueze (2013), should be based on the "5Cs" of credit, which comprise character, capacity, capital, collateral, and condition.

The willingness of a consumer to meet financial obligations is referred to as character. The term "capacity" refers to a customer's ability to pay his debt from his operating cash flows. Conservatism is examined using a broad financial ratio analysis, with a focus on risk ratios including debt-to-asset ratios, current-to-current ratios, and interest-earned-to-interest-paid ratios. This criterion demonstrates the customer's capital sufficiency. Furthermore, collateral refers to the assets that consumers pledge as a guarantee for the loan given. Finally, the requirement refers to the avoidance of economic and other national situations that could affect the customer's ability to pay. Adverse economic conditions may influence a customer's ability or inclination to pay a loan when it is due (Ofoegbu, Duru, \& Onodugo, 2012).

\section{Monitoring Receivables}

Debts should be monitored by the finance manager to ensure that all receivables are collected on time. He should use techniques like the average collection period, the aging schedule, and the collection experience matrix to help him. The average collection period is a credit policy that specifies a credit period that is compared to the calculated average collection period to determine how long it takes to collect an account receivable on average. Cash inflows are hampered by collection delays, which increases the risk of bad debt losses (Kroes \& Manikas, 2014). This scenario would inevitably wreak havoc on the company's liquidity and profitability. This is how the formula is calculated:

$$
\mathrm{ACP}=\mathrm{D} / \mathrm{CS} \times 365 \text { days }
$$

Where:

$\mathrm{ACP}=$ Average collection period;

$\mathrm{D}=$ Debtors, and

$\mathrm{CS}=$ Credit sales

This approach of reviewing and monitoring receivables aids in the tabulation of receivables by debt period. It shows how long the receivables have been outstanding, which is normally within 30 days, 60 days, and 90 days or more (Uwalomwa, Uwuigbe, \& Oyewo 2015). Traditional ways of evaluating receivables include the average collection period and the aging analysis schedule, both of which have drawbacks. Failure to link receivables to sales from the same period is one of the flaws, making control difficult (Owolabi \& Obida, 2012). The collection experience matrix is a scientific method for analyzing collection experience that uses disaggregated data. This method connects receivables to sales from the same time period. The model displays transactions in a horizontal hierarchy and associated receivables in a vertical hierarchy for a particular period.

\section{Liquidity and Profitability Relationship}

Liquidity in the manufacturing environment refers to the amount of cash or near-cash instruments a firm has on hand to pay its obligations immediately or in the short term (Okpala, 2017). The term "sufficient 
liquidity" refers to an entity's ability to satisfy its financial obligations when they become due. Liquidity has a quantity and a time dimension, according to Ezejiofor, Adigwe, and John-Akamelu (2015). Your liquidity is sound if you have cash or quickly realizable assets like government securities. Liquidity is determined by the ability and willingness of debtors to pay. If that is made up of goods, liquidity is determined by their salability, which can be low if they're not in demand. The above statement examines liquidity using current assets and their ability to be converted into cash (Olagunju, David, \& Samuel, 2012; Owolabi \& Obida, 2012). Liquidity is believed to be at its optimum level in this study when credit clients can pay their bills on time, and proper policies are implemented to avoid or reduce bad debt (Muritala \& Taiwo, 2013; Ofoegbu, Duru, \& Onodugo, 2016).

Any business venture's primary goal is to maximize profit, which defines its short-term viability. Profit is important, but management decisions should not be made solely for the sake of profit at the expense of wealth maximization. Profit is defined as the difference between revenues and expenses over a period of time, usually a year, and is considered the final outcome of a business's operations. Without sufficient earnings, a company's future is bleak. Profitability ratios assess a company's overall performance of by analyzing the company's overall performance and viability (Uwuigbe, Uwuigbe, \& Oyewo 2015). The ratios used to quantify profitability are margin and markup, return on equity (ROE), and return on assets (ROA). The leftover profits are distributed to regular stockholders. This means that their return is the net profit after taxes. As a result, the Return on Equity (ROE) is used to determine the profitability of the owners' investment (ROE). The formula is as follows:

\section{ROE $=$ Net profit after tax/Shareholders 'equity}

Also known as Return on Assets, profitability can be assessed by a company's net income expressed as a percentage of total assets available for use (ROA). Companies with higher asset values should be able to make more profits, according to ROA. Management's capacity to effectively employ available assets and achieve good returns is measured by ROA. The formula is as follows:

$$
\text { ROA }=\text { Profit after tax/Total Assets }
$$

\section{Factoring}

Different companies use different credit management approaches as long as the end result is positive. When a finance manager recognizes his company's unique situation, he or she may decide to employ debt risk reduction measures, one of which is factoring. Factoring, also known as debtor finance or receivables factoring, occurs when one company purchases another's debt or invoice (Onuora \& Nwafili, 2017). The debtors' accounts are discounted in this transaction to allow the buyer to profit from the debt settlement. Factoring is the process of transferring ownership of receivable accounts to a third party who will pursue the debt. Factoring buys debt at a discount, releasing the original debtor and providing them with working capital to continue trading, while the debt buyer chases down the loan for the full amount and profits when the receivable is collected (Olarewaju \& Akinleye 2018). Clients can get the information and reports they need regarding market trends and patterns from this element. They also conduct a systematic study of the client's data in order to ensure proper debt monitoring and management (Uwalomwa, Uwuigbe, \& Oyewo, 2015).

\section{Empirical Review}

Numerous studies have been conducted by researchers on credit management and its ability to improve profitability. Muritala and Taiwo (2013) in their studies used ten years of bank data from 2001 to 2010 to examine the relationship between credit management, liquidity position and profitability of some selected banks in Nigeria. The alternative risk absorption hypothesis, according to the study, stipulates efficient credit management, which improves enterprises' ability to create liquidity. Furthermore, it was discovered that return on assets has a large positive impact on current ratio, corroborating the financial fragility crowding out concept. Oyadonghan and Bingilar (2014) examined the effects of effective credit 
policy on the liquidity of manufacturing enterprises in Nigeria and found a link between credit management and liquidity. Liquidity is at a desirable level when a company's credit policy is favorable, according to the study. It also revealed that manufacturing organizations do not constantly check and review their credit policies, and as a result, cash discounts are not allowed as often as they should be. According to Kaitibi, Ganawah, Yokie, Jalloh, and Koroma (2018), who evaluated the influence of efficient credit management on commercial bank profitability in Sierra Leone between 2010 and 2014, credit management shows a positive and significant link with profitability. The findings revealed that the effectiveness of loan management has a substantial impact on the profitability of commercial banks in Sierra Leone. Sabenhang (2015) looked into the impact of credit management on commercial bank performance in Rwanda. The study discovered that there was a substantial link between Equity Bank's financial performance and client appraisal, credit risk management, and collection policy. Between 2006 and 2015, Okpala (2017) conducted research on the relationship between credit management and deposit money bank profitability in Nigeria. The study found that good credit management helps DMBs maintain their financial strength (liquidity), which boosts their profitability. As a result, Kungu, Wanjau, Waititu, and Gekara (2014) investigated the impact of loan policy on manufacturing firm profitability in Kenya. Profitability and credit policy have a significant link, according to the findings. These findings are consistent with those reported by Martnez-Sola et al. (2010) and Khan et al (2012). The finding of Alarcon, on the other hand, contradicted the positive effect of credit management on profitability (2008). The purpose of this study is to determine the importance of trade credit as a means of business financing in the Spanish agro-food industry. Credit policy and liquidity management, according to Onuora and Nwafili (2017), have a significant negative association with Return on Assets.

Liquidity management is critical, especially during times of financial crisis and high costs of getting loans in the financial market, as well as investors' reluctance to engage in company shares due to capital market problems (Owolabi \& Obida, 2012). Owolabi and Obida (2012) investigated the association between liquidity management and corporate profitability in Nigerian manufacturing enterprises. Liquidity management, as assessed by the company's credit policies, cash flow management, and cash conversion cycle, has a considerable impact on profitability, according to the findings. In addition, Ezejiofor, Adigwe, and John-Akamelu (2015) investigated the impact of credit management on the liquidity and profitability of a Nigerian manufacturing firm. According to the findings, there is a link between liquidity situation and debtor turnover, as well as liquidity management and profitability. Trade credit promotes items and increases sales, whereas credit management tactics have a direct relationship with a firm's liquidity situation and an indirect association with profitability, according to the research. Kumaraswamy and George (2019) replicated the association between liquidity management and profit performance in the Nigerian listed pharmaceutical manufacturing subsector (2016). The liquidity ratio and the profitability of the companies were shown to be strongly and favorably connected. The findings of Uzoh (2012) and Ifurueze (2012) support the conclusions of these studies (2013). Omenguele and Mazra (2013) warned that if trade credit isn't properly managed, the system's profitability and performance will suffer.

\section{Gaps and Hypotheses Development}

Most researchers had established the relationship between credit management and liquidity and profitability in the banking sector, according to the literature reviewed in the previous subsection (Muritala \& Taiwo, 2013; Kagoyire \& Shukla, 2016; Kaitibi et al., 2018). However, just a few studies in Nigeria have linked credit management to liquidity and profitability in the industrial sector (Owolabi \& Obida, 2012; Oyadonghan \& Bingilar, 2014; Ezejiofor, Adigwe, \& John-Akamelu, 2015). In the quoted chemical and paints manufacturing sub-sector in Nigeria, it is clear that the relationship between credit management strategy, liquidity, and profitability sub-variables and in aggregate has been deleted from the body of knowledge. This omission left holes in the research, which the current study aimed to fill. To fill in the gaps in the literature, the following null hypotheses (H0) were developed to investigate the relationship between the variables.

- Credit risk assessment has no significant impact on the customer's ability to pay. 
- Debt recovery strategy has no significant influence on the level of the firm's bad debt.

- Receivable collection policy has no significant effect on cash inflow and

- Firm liquidity has no significant influence on profitability.

\section{Theoretical Review}

According to the literature, the supply of trade credit in an unequal situation between the vendor and the customers offers a variety of ideas to explain trade credit's existence and use. Tax theory, liquidity theory, product quality theory, financing advantage theory, pricing discrimination theory, and transaction cost theory are examples of these theories. Although not exhaustive, the preceding list reflects the writers' understanding of trade credit in a Nigerian context (Ali \& Dhiman 2019). To explain the merit supplied to both sellers and purchasers, the financing advantage theory of trade credit and transaction costs theory were employed as the foundation of this study.

\section{Theory of Financing Advantage}

According to the financial advantage idea of trade credit, suppliers may have an advantage over traditional lenders in determining the creditworthiness of their customers, as well as a superior ability to monitor and enforce credit repayment.

In extending credit to a buyer, the seller may have a cost advantage over financial institutions because of the financing advantage (Schwartz, 1974). Gaining knowledge, influencing the buyer, and salvaging the value of existing assets are all cost advantages offered to the credit supplier. When a supplier visits the buyer's location more frequently than financial institutions, it gains an edge in information acquisition. By analyzing the amount and timing of the buyer's orders, as well as his response to taking advantage of early payment to gain discounts, the information may be derived from the buyer's business state. The incapacity of a buyer to take advantage of early payment reductions may disclose the extent of his creditworthiness and serve as a red flag (Chaudhury, 2020).

The nature of the items sold and the seller's position should be examined whether the vendor must control the buyer. If the supplier observes that the buyer has few cost-effective substitute sources, the supplier can threaten to shut off future deliveries if the buyer account represents a small percentage of the provider's total sales volume. In the case that the buyer defaults, the supplier can seize the items given to preserve the value of the current assets. If the items provided are long-lasting, the lien situation may be feasible. As a result, the larger the risk, the more durable the buyer's collateral is (Singh \& Sharma, 2018). If the supplier observes that the buyer has few cost-effective substitute sources, the supplier can threaten to shut off future deliveries if the buyer account represents a small percentage of the provider's total sales volume. In the case that the buyer defaults, the supplier can seize the items given to preserve the value of the current assets. If the items provided are long-lasting, the lien situation may be feasible. As a result, the more durable the buyer's collateral is, the more credit the supplier can extend (Tuladhar, 2017). A financial institution, on the other hand, may have limited capabilities to withdraw future financing, which may have no immediate impact on the borrower's activities. In addition, bankruptcy regulations may limit the financial institution's ability to withdraw previous loans. Financial institutions might potentially seize the company's assets to repay the loan. However, if the supplier already has a network for selling its goods, it can achieve reclamation and resale at a lower cost than the banking institution. Alalade, Binuyo, and Oguntodu (2014), and Taiwo et al. (2017) all employed the financing advantage hypothesis of trade credit.

\section{Transactions Costs Theory}

The buyer's benefit in using trade credit as a form of financing, as well as the seller's cost-cutting strategy, is supported by transaction costs theory. It claims that using trade credit can help you save money on your bill-paying transactions (Uzoh, 2012). Rather than paying bills as soon as items are delivered, a customer with credit sales accumulates responsibilities and pays them only at agreed-upon intervals - weekly, monthly, or quarterly. The vendor would also be able to decouple the payment cycle from the delivery timetable in this way. Other versions of the transaction cost theory are applicable to 
goods with a high degree of seasonality in their consumption patterns. To maintain smooth production cycles, the company may need to build up large inventories, which will result in stock warehousing costs and a reduction in working capital. These costs could be cut by (a) lowering the price of the goods to encourage early sales and demand. Though this may reduce earnings, (b) selectively giving trade credit to consumers and over time to enhance sales and inventory management (Mian \& Smith, 1992). Ezejiofor, Adigwe, \& John-Akamelu, 2015; Kagoyire \& Shukla, 2016; Nwanna \& Oguezue, 2017; Ezejiofor, Adigwe, \& John-Akamelu, 2017; Ezejiofor, Adigwe, \& John-Akamelu, 2017; Ezejiofor, Adigwe, \& John (2017). The trade credit theories of financing advantage and transaction costs are crucial to this study because they explain why both sellers and buyers under trade credit in a perfect market offer and accept trade credit.

\section{METHODOLOGY}

In order to empirically analyze the influence of credit management techniques on liquidity and profitability of quoted industrial goods companies in Nigeria, a descriptive survey study approach was used. This design was chosen because it captures the study's research goals and deals with nonmanipulated complex interactions between variables (Zamira, 2016) As of May 2019, the study's population consisted of 834 management workers (top, medium, and lower level managers) from seven (7) selected listed industrial goods firms in Nigeria. The participants had to meet the following criteria: I have at least 5 years of calculative experience in the industry, (ii) have at least a B.Sc. educational level, and (iii) be involved in trade credit and receivable decision making in the organization. There are ten firms included in the study, these are: DN Meyer Plc, Beta glass Nigeria Plc, CAP Plc, Berger Paints Plc, Dangote Cement Plc, Portland Nigerian Plc, Cutix Plc, Lafarge Plc, Greif Nigeria Plc and Premier Paints Plc. The sample consists of 400 respondents, or $65 \%$ of the overall population, who were chosen at random. The Executive Directors, General Managers, Sales \& Marketing Managers, Finance Managers, Accountants and others were chosen as participants.

5 points for 20 items The Likert-scale response instrument was created by the researcher and divided into sections A and B for demographic data and sections B to E for inferential data. The answers to the questions in each section about the quantity of relationships between variables were coded as follows: $1=$ Weak. 2 indicates a slight weakness, 3 indicates an average performance, 4 indicates a strong performance, and 5 indicates a very high performance. To reach relevant analysis and conclusion, the respondents' impressions and opinions were recorded and assessed. Exploratory factor analysis was used in the research instrument to see if the proposed variable indicators had significant factor loadings and to choose the best model for the study.

At a 5\% level of significance, descriptive statistics and regression analysis were used to assess the primary data gathered. The descriptive statistics were determined using a one-way ANOVA to determine the average respondents' perception and the mean score on each of the three constructs. In addition, a basic regression analysis method was used to examine the impact of credit management strategy on liquidity and profitability in Nigeria's publicly traded industrial goods firms. The rule was that the independent variable's probability value was compared to a critical value of $5 \%$.

Credit management strategies, which are separated into three proxies: credit risk assessment approach, debt recovery strategy, and credit collection strategy, are the independent variables. Liquidity is the dependent variable, which is divided into three sub-variables: ability to pay, bad debt level, and cash inflow, which is thought to have the potential to modify profitability. The variables employed in the investigation were described in Table 1.

Table 1. Depiction of Variables Used in the Study

\begin{tabular}{|l|l|l|l|}
\hline Variables & Abbre & Status & Definition \\
\hline $\begin{array}{l}\text { Credit risk } \\
\text { assessment } \\
\text { strategy }\end{array}$ & CRA & Independent & $\begin{array}{l}\text { This is an examination of a prospective credit customer's } \\
\text { information to determine whether the customer will be able } \\
\text { to meet his commitments under the terms of the contract. }\end{array}$ \\
\hline
\end{tabular}




\begin{tabular}{|l|l|l|l|}
\hline $\begin{array}{l}\text { Credit } \\
\text { Management } \\
\text { Strategies }\end{array}$ & CMS & Independent & $\begin{array}{l}\text { Are plans by a firm to guarantee that credit sales are kept } \\
\text { under control, receivables are collected on time, and bad debt } \\
\text { losses are kept to a minimum in order to meet the firm's goals. }\end{array}$ \\
\hline $\begin{array}{l}\text { Credit } \\
\text { collection } \\
\text { strategy }\end{array}$ & RCP & Independent & $\begin{array}{l}\text { This is a set of receivables collection policies that control how } \\
\text { a company extends credit and collects receivables. }\end{array}$ \\
\hline $\begin{array}{l}\text { Debt } \\
\text { recovery } \\
\text { strategy }\end{array}$ & DRS & Independent & $\begin{array}{l}\text { This is a method that aids a company in debt collection by } \\
\text { lowering costs, shortening collection time, and increasing } \\
\text { liquidity. }\end{array}$ \\
\hline Profitability & PRO & Dependent & $\begin{array}{l}\text { This is the amount of profit or financial gain generated by an } \\
\text { organization's activities. It's calculated by subtracting total } \\
\text { expenses from total revenue over the same time period. }\end{array}$ \\
\hline Liquidity & LID & Dependent & $\begin{array}{l}\text { Liquidity refers to how much cash or close cash a company } \\
\text { has on hand to pay short-term obligations. }\end{array}$ \\
\hline Bad debt. & LBD & Dependent & $\begin{array}{l}\text { A bad debt is a sum of money owing to a creditor that is } \\
\text { unlikely to be repaid. }\end{array}$ \\
\hline Cash inflow & CFL & Dependent & $\begin{array}{l}\text { The net amount of cash and cash equivalents transferred into } \\
\text { a business is referred to as cash inflow. }\end{array}$ \\
\hline $\begin{array}{l}\text { Ability } \\
\text { pay to }\end{array}$ & ATP & Dependent & $\begin{array}{l}\text { This is a financial theory that demonstrates a credit } \\
\text { customer's ability to pay his obligation when it is due. }\end{array}$ \\
\hline
\end{tabular}

Source: Researchers' Compilation (2021)

Other dummy variables in this study include the credit manager's expertise, industry restrictions, the type of credit items sold, and the usage of collateral as security. These variables, however, were not employed in the regression analysis because they expected a value of " $0 . "$

\section{Econometric Specification}

At a 5\% level of significance, the data were examined using a descriptive and basic regression approach. $\mathrm{LID}+\mathrm{PRO}=\mathrm{f}$ is the functional form of the model specification (CMA). Where LID stands for liquidity, with ATP, LBD, and CFL as sub-variables as a function of credit management approach (CMS). CRA, DRS, and RCP are all proxies for the CMS. The following are the linear regression equations that were used adopted from Ehiedu (2014) with modification:

Impact of credit risk assessment on customer's ability to pay the debt

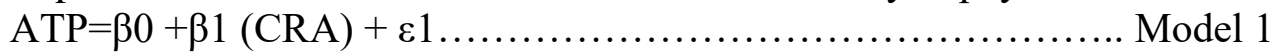

Impact of debt recovery strategy on the company's level of bad debt.

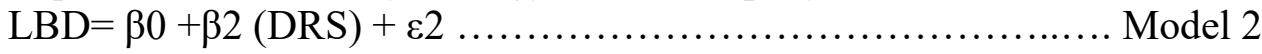

Impact of credit collection policy on cash inflow

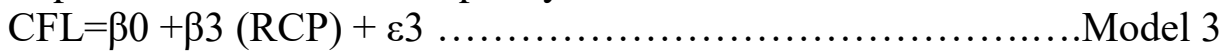

Impact of liquidity on profitability

$\mathrm{PRO}=\beta 0+\beta 4(\mathrm{LID})+\varepsilon 4$ Model 4

The overall model for the study is indicated as follow:

Influence of firm liquidity on profitability

$\mathrm{LID}+\mathrm{PRO}=\beta 0+\beta 1(\mathrm{CMS})+\varepsilon$

Where: $\mathrm{CMS}=(\mathrm{CRA})+(\mathrm{DRS})+(\mathrm{RCP})$ 
$\mathrm{LID}+\mathrm{PRO}=\beta 0+\beta 1(\mathrm{CRA})+\beta 2(\mathrm{DRS})+\beta 3(\mathrm{RCP})+\varepsilon \ldots \ldots$ Model 5

A prior expectation $\mathrm{CRA}>0, \mathrm{DRS}>0, \mathrm{RCP}>0$

\section{DATA ANALYSIS AND INTERPRETATION OF STATEMENTS}

A total of 400 copies of the questionnaire were distributed to the sample population, and 355 copies were returned, reflecting a response rate of 89 percent. The data were collected and analyzed using descriptive and regression analysis to test the null hypotheses about the effect of credit management strategy on liquidity and profitability.

\section{Descriptive Statistics}

To summarize the average respondents' perceptions of each of the credit management strategy subvariables - credit management, credit risk assessment, and debt recovery plan - descriptive statistics were conducted using one-way ANOVA.

\section{One-Way Analysis of Variance (ANOVA)}

Table 2. Summary of Results (One - way ANOVA)

\begin{tabular}{|l|l|l|l|l|l|l|l|l|l|}
\hline Firms & \multicolumn{3}{l}{ CRS (Model 1) } & \multicolumn{3}{l|}{ DRS (Model 2) } & \multicolumn{3}{l|}{ RCP (Model 3) } \\
\hline & $\mathbf{N}$ & Mean & SD & N & Mean & SD & N & Mean & SD \\
Meyer Plc & 37 & 3.442 & 0.344 & 37 & 4.452 & 0.346 & 37 & 3.843 & 0.238 \\
Beta Glass & 40 & 3.028 & 0.354 & 40 & 4.465 & 1.456 & 40 & 3.665 & 0.357 \\
Greif Plc & 41 & 3.502 & 0.564 & 41 & 4.028 & 0.453 & 41 & 3.583 & 0.448 \\
CAP Plc & 36 & 3.243 & 1.345 & 36 & 4.922 & 0.982 & 36 & 3.879 & 0.639 \\
Lafarge Plc & 40 & 3.345 & 0.657 & 40 & 4.502 & 0.485 & 40 & 3.658 & 1.338 \\
Cutix Plc & 38 & 3.452 & 1.024 & 38 & 4.563 & 0.398 & 38 & 3.904 & 0.511 \\
Premier Paint & 30 & 3.112 & 0.376 & 30 & 4.237 & 1.398 & 30 & 3.831 & 0.378 \\
Berger Paint & 39 & 3.426 & 1.101 & 39 & 4.598 & 0.765 & 39 & 3.773 & 0.444 \\
Portland & 25 & 3.246 & 0.345 & 25 & 4.722 & 0.439 & 25 & 3.905 & 0.346 \\
Dangote & 29 & 3.222 & 0.392 & 29 & 4.832 & 0.267 & 29 & 3.643 & 0.398 \\
Total & $\mathbf{3 5 5}$ & $\mathbf{3 . 3 0 2}$ & $\mathbf{0 . 6 5 0}$ & $\mathbf{3 5 5}$ & $\mathbf{4 . 5 3 9}$ & $\mathbf{0 . 6 9 9}$ & $\mathbf{3 5 5}$ & $\mathbf{3 . 7 6 8}$ & $\mathbf{0 . 5 1 0}$ \\
F- statistics & $\mathbf{2 2 . 3 4}$ & & & $\mathbf{2 4 .}$ & & & $\mathbf{2 0 . 8 6}$ & & \\
& & & & $\mathbf{1 1}$ & & & & & \\
P-value & $\mathbf{0 . 0 1 2}$ & & & $\mathbf{0 . 0}$ & & & $\mathbf{0 . 0 0 9}$ & & \\
& & & & $\mathbf{3 5}$ & & & & & \\
\hline
\end{tabular}

Source: Researcher's Computation

Note: $\mathrm{CRA}=$ Credit risk assessment; DRS = Debt recovery strategy; RCP = Receivables collection policy

Hypothesis 1: Credit Risk Assessment has No Significant Impact on the Customer's Ability to Pay As demonstrated in Table 2, Model 1, the average opinion of each population strata suggested a strong but mixed perception of the impact of credit risk assessment on customer ability to pay in each category. When all the items were collapsed, the overall average impression of all categories yielded a total mean score of 3.302, with an F- value of 22.34. With a P-value of $0.012<0.05$, the differences in mean impression of the ten firms were statistically significant. As a result, the aggregate mean score of respondents' opinions between the CRA and the ATP suggests that credit risk assessment is strongly linked to the customer's ability to pay. This falls above "slightly strong" option on the scale of 1 to 5 on the research instrument. 


\section{Hypothesis 2: Debt Recovery Strategy has No Significant Influence on the Company's Level of Bad Debt}

As demonstrated in Table 2, Model 2, the average view of each population strata suggested a high but mixed perception of the impact of debt recovery strategy on the company's level of bad debt in each category. When all the items were collapsed, the overall average perception of all classes yielded a total mean score of 4.539 , with an F- value of 24.11 . With a P-value of $0.035<0.05$, the differences in mean assessment of the ten firms were statistically significant. As a result, based on the total mean score of respondents' opinions between the DRS and BDE, debt recovery method appears to be firmly tied to the company's amount of bad debt. This falls within the "strong" option on the scale of 1 to 5 on the research instrument.

\section{Hypothesis 3: Receivable Collection Policy has No Significant Effect on Cash Inflow}

In Table 2, model 3, the common view of each population section revealed a strong but mixed opinion in each group on the impact of receivable collection policy on cash inflow. When all the items were compressed, the overall average perception of all categories resulted in a total mean score of 3.768, with an F- value of 20.86 . With a P-value of $0.009<0.05$, the variations in the mean viewpoint of the ten firms were statistically significant. As a result, based on the overall mean score of respondents' opinions between the RCP and CFL, the receivable collection policy is highly related to the degree of cash inflow. This falls within the "strong" option on the scale of 1 to 5 on the research instrument.

\section{Test of Hypotheses}

Table 3. Summary of Regression Results of the impact of credit management strategy on Firms' Profitability

\begin{tabular}{|c|c|c|c|c|c|}
\hline & $\mathbf{N}$ & Model 1 & Model 2 & Model 3 & Model 4 \\
\hline $\begin{array}{l}\text { Model Summary } \\
\text { R } \\
\text { R2 } \\
\text { Adj. R2 }\end{array}$ & 355 & $\begin{array}{l}0.554 \\
0.592 \\
0.521 \\
\end{array}$ & $\begin{array}{l}0.498 \\
0.589 \\
0.573 \\
\end{array}$ & $\begin{array}{l}0.472 \\
0.640 \\
0.581 \\
\end{array}$ & $\begin{array}{l}0.643 \\
0.601\end{array}$ \\
\hline \multicolumn{6}{|l|}{ ANOVA } \\
\hline $\begin{array}{l}\text { Sig. } \\
\text { F. Statistics }\end{array}$ & 355 & $\begin{array}{l}0.005 \\
18.321\end{array}$ & $\begin{array}{l}0.025 \\
16.477\end{array}$ & $\begin{array}{l}0.017 \\
14.528\end{array}$ & 0.000 \\
\hline \multicolumn{6}{|l|}{ Coefficients } \\
\hline $\begin{array}{l}\text { t- statistics } \\
\text { ( Constant) } \\
\text { CRA, DRS, RCP } \\
\text { Std. Error } \\
\text { DW }\end{array}$ & 355 & $\begin{array}{l}10.532 \\
4.617 \\
0.421 \\
0.043 \\
2.342\end{array}$ & $\begin{array}{l}8.912 \\
3.839 \\
0.568 \\
0.064 \\
1.346\end{array}$ & $\begin{array}{l}9.487 \\
3.541 \\
0.462 \\
0.0867 \\
1.092\end{array}$ & $\begin{array}{l}7.367 \\
4.783 \\
0.576 \\
0.053 \\
2.003\end{array}$ \\
\hline
\end{tabular}

Source: Researcher's Computation

The bivariate analysis of hypotheses 1,2 , and 3 revealed that $R=0.554,0.592$, and 0.521 for the three constructs, respectively, as shown in Table 3. These findings show that independent variable proxies (credit risk assessment, debt recovery technique, and receivable collection policy) have a favorable impact on dependent sub-variables (ability to pay, bad debt level, and cash inflow). The Fstatistics of $18.321,16.477$, and 14.528 support this. The R2 values of $0.592,0.573$, and 0.581 indicated that CRA, DRS, and RCP were responsible for 52 percent, 57 percent, and 58 percent of the variation in liquidity and profitability of quoted industrial goods businesses in Nigeria, respectively. The independent sub-variables had statistically significant effects on dependent sub-variables $(\mathrm{P}=0.005$, 0.025 , and 0.017 ). The t-statistics of $10.532,8.912$, and 9.487 verified this. The null hypotheses 1 to 3 were rejected based on the data presented above, whereas other hypotheses were not. ATP $=4.617+$ 
0.421 (CRA); $\mathrm{BDE}=3.839+0.568(\mathrm{DRS})$; and $\mathrm{CFL}=3.541+0.462(\mathrm{CFL})$ are the basic linear equations for the three structures (RCP). In the industrial goods sector in Nigeria, a unit increase in CRA, DRS, and RCP would push 42 percent, 57 percent, and 46 percent increases in ATP, LBD, and CFL, respectively.

The overall $\mathrm{R}=0.643$, indicating that liquidity (LID) has a considerable positive impact on profitability, according to the results of null hypotheses 4 . (PRO). LID was responsible for $60 \%$ of the variation in the PRO in the industrial goods sector in Nigeria, according to the R2 $=0.601$ result. LIDS had a statistically significant effect on PRO $(\mathrm{P}=0.000<05) . \mathrm{PRO}=4.783+0.576$ (LID) was the simple linear equation, which meant that a unit change in LID resulted in a 57 percent rise in PRO. As a result, null hypothesis 4 is rejected, while the alternate hypothesis is not. Based on the statistically significant positive effective of the CMS three components, it can be concluded that the CMS multi-variance has adequately described liquidity and profitability in aggregate. Hypotheses one to four produce results that are consistent with the a priori expectation: $\mathrm{CRA}>0, \mathrm{DRS}>0, \mathrm{RCP}>0$.

\section{Discussion of Findings}

The findings of Muritala and Taiwo (2013), who said that return on assets has a strong positive effect on current ratio, supported Hypothesis 1,2, and 3, validating the financial fragility crowding out hypothesis. Also, according to Oyadonghan and Bingilar (2014), a favorable company's credit policy pushes a desirable degree of liquidity. The findings are also consistent with Kaitibi et al. (2018)'s report, which concluded that better bank profitability in Sierra Leone was due to effective lending policy. These hypotheses were supported by the report studies of Martnez-Sola et al. (2010); Khan et al. (2012); Kungu et al. (2014); Kagoyire and Shukla (2016); Ofoegbu, Duru, \& Onodugo, (2016); Nwanna and Oguezue, (2016); Martnez-Sola et al. (2010); Khan et al. (2012); Khan et al. (2012); Khan et al. (2012); Khan et al. (2017). However, the findings of this study contradict those of Alarcon (2008), who asserted that while credit management may promote items and increase sales, it will impair financial system profitability and performance if not properly managed. The findings also contradicted Onuora and Nwafili (2017), who found a significant negative link between credit policy and liquidity management and return on assets. Hypothesis 4 demonstrated not just a positive but also a significant association between liquidity and profitability. Ifurueze (2013), Owolabi and Obida (2012); Ismail (2016); Jindal, Jain, and Vartika (2017); and Ezejiofor, Adigwe, and John-Akamelu (2013) all came to similar conclusions (2015).

\section{Summary of Findings}

\section{SUMMARY, CONCLUSION AND RECOMMENDATIONS}

Credit management strategies are plans of action aimed to guarantee that trade credit is granted and controlled appropriately. It would improve receivable collection from trade debtors by implementing appropriate methods, resulting in improved sales volume, total revenue, and lower financial risks. The goal of this research is to see how credit management tactics affect liquidity and profitability. This was determined by examining the influence of credit risk assessment strategy on customers' ability to pay, the impact of debt recovery strategy on bad debt levels, and the impact of credit collection method on cash inflow levels. The fourth sub-objective looked at the impact of liquidity on profitability as a moderating factor. The following is a summary of the research findings based on the analysis: 1 . Hypotheses one to three revealed that the three tactics of credit risk assessment, debt recovery, and credit collection all had a positive and significant impact on a company's liquidity as assessed by customer ability to pay, bad debt level, and cash inflow. 2. Giving customer's credit would enhance sales and raise the industry's market share. 3. Credit management solutions increase liquidity through proper plans of action, improve receivable collections, and help the organization achieve its goals. 4. Adequate liquidity allows businesses to take advantage of the cash discount rate and engage in initiatives with a positive net present value, which boosts profits. 


\section{Conclusion}

Credit management strategies, as measured by credit risk assessment, debt recovery strategy, and credit collection strategy, have a positive and significant impact on liquidity and profitability of quoted industrial goods firms in Nigeria, according to the findings of this study. The following is a policy recommendation based on the study's findings:

- The customer's capacity to pay is influenced by the credit risk assessment strategy. Setting a credit period, evaluating the degree of the durability of collateral presented as security before credit is granted, offering rebates to speed up receivables collections, and raising an invoice as a credit instrument for transaction proof are all requirements for organizations in this industry. The controller should review financial accounts of customers and determine their creditworthiness to assess consumer information and avoid risk.

- The company's bad debt level is influenced by the debt recovery approach. To facilitate debt recovery, debt recovery plans should be established and implemented, particularly for overdue debts resulting from credit sales to customers. This would aid businesses in increasing receivable collections and reducing bad debt losses.

- The way you collect receivables has a big impact on your cash flow.

\section{Recommendations}

Industrial goods sector in Nigeria should pay particular attention to receivables and liquidity. When properly managed, this initiative is likely to have an impact on the company's financial performance. The study thus, suggest that companies in the industry should enhance their liquidity in order to achieve the targeted profit level by having effective credit terms and proper risk assessment strategy, designing and implementing debt recovery plans to aid collection of the overdue debt, adopting a stringent credit collection method, and employing and retained qualified accountants and credit administrators with excellent knowledge of credit control techniques

\section{REFERENCES}

Adegboye, O. D. (2021). The Liquidity and Profitability Tradeoff of Commercial Banks in Nigeria. Open Journal of Management Science (ISSN: 2734-2107), 2(2), 17-26.

Agu, O. C. \& Basil, C. O. (2013). Credit management and bad debt in Nigeria commercial Banks: Implication for development. Journal of Humanities and Social Science, 12(1), 47-56.

Akinleye, G. T., \& Olarewaju, O. O. (2019). Credit Management and Profitability Growth in Nigerian Manufacturing Firms. Acta Universitatis Danubius: Oeconomica, 15(2), 445-456.

Akinsulire, O. (2017). Financial management (7th ed.). Lagos: Ceemol Nigeria Limited.

Alalade, S., Binuyo, O. \& Oguntodu, A. (2014). Managing credit risk to optimize banks profitability: A Survey of selected banks in Lagos State, Nigeria. Research Journal of Finance and Accounting, 5(18), 76-84.

Ali, L., \& Dhiman, S. (2019). The impact of credit risk management on profitability of public sector commercial banks in India. Journal of Commerce and Accounting Research, 8(2), 86-92.

Banu, M. H., Sayaduzzaman, M., \& Sil, S. C. (2021). The Impact of Credit Risk Management Indicators on Profitability Attributes: Evidence from the State-Owned Commercial Banks in Bangladesh. American Journal of Trade and Policy, 8(3), 215-224. 
Chaudhury, N. J. (2020). The efficacy of liquidity management of Bangladeshi commercial banks: does liquidity underscore bank profitability?. International Journal of Financial Services Management, 10(3), 268-283.

Ehiedu, V. C. (2014). The impact of liquidity on profitability of some selected companies: The financial Statement analysis (FSA) approach. Research Journal of Finance and Accounting, 5(5), 81-90.

Ezejiofor, R. A., Adigwe, P. K., \& John-Akamelu, R. C. (2015). The effect of credit management on liquidity and profitability positions of a manufacturing company in Nigeria. European Journal of Research and Reflection in Management Sciences, 3(3), 32 - 48.

Ferris, J. S. (1981). A transactions theory of trade credit use. Quarterly Journal of Economics, 96(2), $243-270$

Ifurueze, M. S. K. (2013). The impact of effective management of credit sales on profitability and liquidity of food and beverage industries in Nigeria. Global Journal of Management and Business Research, 13(2), 29-38.

Ismail, R. (2016). Impact of liquidity management on profitability of Pakistani firms: A case of KSE100 Index. International Journal of Innovation and Applied Studies, 14(2), 304.

Jindal, D., Jain, S., \& Vartika, K. (2017). Effect of receivables management on profitability: A study of commercial vehicle industry in India. Management, 2(2), 246-255.

Kaitibi, D. B., Ganawah, E. T. J., Yokie1, M. A., Jalloh, M., \& Koroma, B. M. (2018). Impact of efficient credit management on profitability of commercial banks in Sierra-Leone. Open Journal of Business and Management, 6(1), 139-150.

Kagoyire, A., \& Shukla, J. (2016). Effect of credit management on performance of commercial banks in Rwanda (a case study of Equity Bank Rwanda Ltd). International Journal of Business and Management Review, 4(4), 1-12,

Kamal, A. A. (2021). CREDIT Risk Management and Profitability (Pat) Of Deposit Money Banks (DMBS) In Nigeria. Ede Journal of Business (EJOB), 8(1), 54-65.

Khan, M. A., Tragar, G. A., \& Bhutto, N. A. (2012). Determinants of accounts receivable and accounts payable: a case of Pakistan textile sector. Interdisciplinary Journal of Contemporary Research in Business, 3(9), 240-251.

Kumaraswamy, S., \& George, S. (2019). Trade credit management and firm profitability of Saudi manufacturing firms. Polish Journal of Management Studies, 20(1), 243-253.

Kroes, J. R., \& Manikas, A. S. (2014). Cash flow management and manufacturing firm financial performance: A longitudinal perspective. International Journal of Production Economics, 148, 37-50. http://dx.doi.org/10.1016/j.ijpe.2013.11.008

Kungu, J. N., Wanjau, K. L., Waititu. A. G., \& Gekara, G. M. (2014). Effects of credit policy on profitability of manufacturing firms in Kenya. IOSR Journal of Economics and Finance (IOSR$J E F), 2(4), 01-07$ 
Kwenda, F. (2014). Trade credit in Zimbabwe's economic recovery. Mediterranean Journal of Social Sciences, 5(2), 431- 39.

Madushanka, K. H. I., \& Jathurika, M. (2018). The impact of liquidity ratios on profitability. International Research Journal of Advanced Engineering and Science, 3(4), 157161.

Martínez-Sola, C., García-Teruel, P. J., \& Martínez-Solano, P. (2014). Trade credit and SME profitability. Small Business Economics, 42(3), 561-577.

Muritala, T. A., \& Taiwo, A. S. (2013). An empirical evidence on impact of credit management and Liquidity position on profitability of Nigerian banking sector. Management and Administrative Sciences Review, 2(2), 233-242

Nwanna, I. O., \& Oguezue, F. C. (2017). Effect of credit management on profitability of deposit money banks in Nigeria. IIARD International Journal of Banking and Finance Research, 3(2), 137 160.

Ofoegbu, G. N., Duru, N., \& Onodugo, V. (2016). Liquidity Management and Profit Performance of Pharmaceutical. International Journal of Management Sciences and Business Research, 5(7), 113.

Okpala, K. E. (2017). Strategic Budgetary System and Infrastructure Development of the Power sector in Nigeria, 1981-2015. (Unpublished Ph.D. thesis, Department of Business Administration and Marketing of Babcock Business School.

Okpala, K. E., Osanebi, C., \& Irinyemi, A. (2019). The impact of credit management strategies on liquidity and profitability. Journal of Behavioural Studies, 1(1), 1-14.

Olabisi, J., Oladejo, D. A., Adegoke, J. F., \& Abioro, M. A. (2019). Credit Management Policy and Firms'profitability: Evidence from Infant Manufacturing Firms in Southwest, Nigeria. Contemporary Economy Journal, 4(4), 59-69.

Olarewaju, O. O., \& Akinleye, G. T. (2018). Credit Management and Profitability Growth as a Measure of Manufacturing Firm's Growth in Nigeria. Acta Universitatis Danubius. Economica, 15(2), $445-456$

Onuora, J. K., Nwafili, I. S. (2017). The Effects of Credit Management on Profitability of manufacturing firm in Nigeria. (A Study of Selected Companies in Nigerian Stock Exchange). Research Journal of Finance and Accounting, 8(10), 142 -154

Owolabi, S. A., \& Obida, S. S. (2012). Liquidity management and corporate profitability: Case study of selected manufacturing companies listed on the Nigerian Stock Exchange. Business Management Dynamics, 2(2), 10 - 25.

Oyadonghan, K. J., \& Bingilar, P. F. (2014). The impact of effective credit policy on liquidity of manufacturing companies in Nigeria. European Journal of Accounting Auditing and Finance Research, 2(7), 88-100. 
Raymond, A. E., \& Adigwe, P. K. (2015). The credit management on liquidity and profitability positions of a manufacturing company in Nigeria. European Journal of Research and Reflection in Management Sciences, 3(3), 32-48.

Sabenhang, H. K. (2015). Credit Management and Its Impact on Profitability of Joint Venture Banks in Nepal (Doctoral dissertation, Faculty of Management Tribhuvan University).

Schwartz, R. A. (1974). An economic model of trade credit. Journal of Financial and Quantitative Analysis, 9(4), 643 - 657.

Singh, S., \& Sharma, D. K. (2018). Impact of credit risk on profitability: A study of Indian public sector banks. International Journal of Research in Economics and Social Sciences (IJRESS), 8(2), 492-498.

Taiwo, J. N., Ucheaga, E. G., Achugamonu, B. U., Adetiloye, K., \& Okoye, O. (2017). Credit risk management: Implications on bank performance and lending growth. Saudi Journal of Business and Management Studies, 2(5B), 584-590.

Tuladhar, R. (2017). Impact of credit risk management on profitability of Nepalese commercial banks (Doctoral dissertation, Western Sydney University (Australia).

Uwalomwa, U., Uwuigbe, O. R. \& Oyewo, B. (2015). Credit management and bank performance of listed banks in Nigeria. Journal of Economics and Sustainable Development, 6(2), 27-32.

Uwuigbe, U., Uwuigbe, O. R., \& Oyewo, B. (2015). Credit management and bank performance of listed banks in Nigeria. Journal of Economics and Sustainable Development, 6(2), 27-32.

Uzoh, C. A. (2012). The impact of credit management on the profitability of a manufacturing firm: A Case study of Unilever Plc Aba, Nigeria. (Unpublished M.Sc. Thesis, Department of Accounting, University of Nigeria, Enugu, Nigeria.

Wireko, D., \& Forson, A. (2017). Credit Risk Management and Profitability of Selected Rural Banks in Upper East Region. Journal of Excellence, Leadership, \& Stewardship, 6(2), 43-55.

Zamira, V. (2016). The impact of credit risk management on the banking profitability: a Survey of the theoretical and empirical literature. European journal of economics and management sciences, (2), 48-51.

\section{Copyrights}

Copyright for this article is retained by the author(s), with first publication rights granted to the journal. This is an open-access article distributed under the terms and conditions of the Creative Commons Attribution license (https://creativecommons.org/licenses/by/4.0) 